\title{
Analisis Kemampuan Penalaran Matematis Siswa Kelas V dengan Menggunakan Model Pembelajaran Jigsaw dan Numbered Head Together (NHT)
}

\author{
Dita Shinta Paramytha* \\ Universitas Negeri Malang, Jl. Semarang No. 5 Malang, Jawa Timur, Indonesia \\ *Penulis korespondensi, Surel: dita.shinta.1601516@students.um.ac.id
}

Paper received: 1-4-2021; revised: 22-4-2021; accepted: 29-4-2021

\begin{abstract}
Mathematical reasoning ability is an ability that needs to be trained. To improve it, an attractive learning model is needed and requires active students. The purpose of the study was to explain the differences in students' mathematical reasoning abilities using a quasi-experimental quantitative method. Data obtained from pre-test and post-test data. The results showed no difference in the mathematical reasoning ability of fifth grade students using the Jigsaw and NHT learning models as evidenced by 0.878 smaller than 2.002. Sig. Value (2-tailed) bigger than 0.05 which is 0.384 bigger than 0.05 .
\end{abstract}

Keywords: mathematical reasoning ability; jigsaw; numbered head together (NHT)

\begin{abstract}
Abstrak
Kemampuan penalaran matematis merupakan kemampuan yang perlu dilatih. Untuk meningkatkannya, perlu model pembelajaran yang menarik dan menuntut siswa aktif. Tujuan penelitian untuk menjelaskan perbedaan kemampuan penalaran matematis siswa menggunakan metode kuantitatif kuasi eksperimen. Data diperoleh dari data pre-test dan post-test. Hasil penelitian menunjukkan tidak ada perbedaan kemampuan penalaran matematis siswa kelas $\mathrm{V}$ dengan menggunakan model pembelajaran Jigsaw dan NHT dibuktikan dengan 0,878 kurang dari 2,002. Nilai Sig. (2-tailed) lebih dari 0,05 yaitu 0,384 lebih dari 0,05.
\end{abstract}

Kata kunci: kemampuan penalaran matematis; jigsaw; numbered head together (NHT)

\section{Pendahuluan}

Matematika memiliki peranan yang sangat penting bagi kehidupan. Herman (2007) mengemukakan bahwa perkembangan pendidikan matematika berjalan beriringan dengan perkembangan teknologi dan tuntutan kehidupan sosial. Berbekal kemampuan berfikir kritis dan sistematis dalam pembelajaran matematika, siswa akan mampu memecahkan masalah. Dalam menyelesaikan masalah di kehidupan sehari-hari, siswa memerlukan kemampuan bernalar yang baik. Annisah, dkk. (2011) menyatakan bahwa kunci utama keberhasilan dalam menyelesaikan masalah matematika adalah penalaran matematis. Menurut Sumartini (2015) dengan adanya penalaran matematis, siswa dapat membuat asumsi kemudian merangkai bukti, memanipulasi permasalahan serta menyimpulkan dengan benar dan tepat. Sehingga dengan penalaran matematis siswa mampu membuat kesimpulan dari permasalahan matematika.

Menurut Andira, dkk. (2018) mengemukakan bahwa dalam pembelajaran matematika dibutuhkan kemampuan guru mendesain pembelajaran dengan pendekatan atau metode yang tepat. Sehingga dampak dari pembelajaran matematika dapat membentuk siswa mempunyai kemampuan memahami konsep, kemampuan komunikasi, kemampuan pemecahan masalah, 
dan kemampuan penalaran. Salah satu preferensi model pembelajaran yang dapat digunakan adalah pembelajaran kooperatif. Menurut Salam dan Junta (2012) model pembelajaran kooperatif merupakan kegiatan bergotong royong dalam satu kelompok untuk mencapai sebuah keberhasilan. Keberhasilan tersebut dapat tercapai apabila terdapat keterlibatan dari setiap anggota kelompoknya. Rahmiati dan Pianda (2018) mengemukakan bahwa kerja sama siswa dalam kelompok kecil sangat diutamakan dalam pembelajaran kooperatif. Sehingga siswa dapat mempunyai sikap gotong royong, kemampuan komunikasi, dan penalaran matematis.

Namun, siswa kurang tertarik dan kurang menguasai materi matematika sehingga memerlukan waktu yang lama pada saat mengerjakan soal. pengerjaan secara kelompok jarang dilakukan. Terbukti dari hasil wawancara peneliti pada guru SDN Kedungringin III, Kecamatan Beji, Kabupaten Pasuruan. Sehingga peneliti tertarik untuk meneliti kemampuan penalaran matematis siswa kelas $\mathrm{V}$ sebagai bahan pertimbangan model pembelajaran yang baik untuk mencapai tujuan pembelajaran. Penelitian ini bertujuan untuk mengetahui perbedaan kemampuan penalaran matematis siswa kelas $\mathrm{V}$ dengan menggunakan model pembelajaran Jigsaw dan Numbered Head Together (NHT).

\section{Metode}

Pendekatan yang digunakan dalam penelitian ini yaitu pendekatan kuantitatif. Penelitian ini menggunakan jenis penelitian kuasi eksperimen. Analisis ini dilakakuan untuk mengetahui perbedaan kemampuan penalaran matematis antara siswa yang belajar dengan menggunakan model pembelajaran Jigsaw dengan siswa yang belajar dengan menggunakan model pembelajaran NHT pada mata pelajaran Matematika materi volume bangun ruang Kelas V SDN Kedungringin III Kecamatan Beji Kabupaten Pasuruan. Teknik pengumpulan data pada penelitian ini menggunakan teknik tes dan dokumentasi. Dokumen yang digunakan dalam penelitian ini, yaitu data hasil kegiatan siswa saat mengerjakan soal pre-test, kegiatan pada saat pemberian perlakuan dan mengerjakan soal post-test. Analisis data yang digunakan dalam penelitian ini yaitu uji prasyarat yang terdiri dari uji normalitas dan uji homogenitas, setelah itu baru uji hipotesis. Uji hipotesis dalam penelitian ini menggunakan uji independent sample ttest dan penghitungannya menggunakan bantuan SPSS 23.

\section{Hasil dan Pembahasan}

Pada hasil analisis data kemampuan awal siswa sebelum diberi perlakuan menunjukkan kelas eksperimen Jigsaw memiliki rata-rata 65,4, kelas eksperimen NHT memiliki rata-rata 62,79. Selisih rata-rata kedua kelas eksperimen adalah 2,61. Data kemampuan akhir siswa sesudah diberi perlakuan menunjukkan kelas eksperimen Jigsaw memiliki rata-rata 78,4. Kelas eksperimen NHT memiliki rata-rata 75,95.

Hasil analisis data kemampuan siswa sebelum dan sesudah diberi perlakuan menunjukkan kelas eksperimen Jigsaw dan NHT mengalami peningkatan. Hal ini dikarenakan terdapat perbedaan perlakuan, baik terhadap kelas eksperimen Jigsaw maupun kelas eksperimen NHT. Menurut Aeni (2008) yang menyatakan pendekatan kooperatif tipe Jigsaw berhasil meningkatkan kemampuan penalaran siswa dalam pembelajaran matematika. Manshur (2013) mengatakan Jigsaw didesain untuk meningkatkan rasa tanggungjawab siswa terhadap pembelajaran yang dipelajarinya dan juga pembelajaran yang dipelajari orang lain.

Sejalan dengan Jelatu, dkk. (2019), dapat diketahui bahwa kemampuan penalaran matematis siswa yang diajarkan dengan tipe NHT lebih baik jika dibandingkan dengan 
kemampuan penalaran matematis siswa yang diajarkan secara klasikal.Hasil pembuktian validitas isi instrumen pre-test dan post-test menggunakan rumus Aiken dengan bantuan Microsoft Excel bahwa seluruh soal dapat digunakan dalam penelitian. Hasil pembuktian validitas isi instrumen RPP Jigsaw dan RPP NHT menggunakan rumus Aiken dengan bantuan Microsoft Excel dilihat bahwa RPP memenuhi seluruh aspek penilaian sehingga dapat digunakan dalam penelitian. Uji reliabilitas dalam penelitian ini menggunakan rumus Alpha Cronbach dengan bantuan SPSS 23. Hasil perhitungan reliablitas pre-test Jigsaw, pre-test NHT, post-test Jigsaw, dan post-test NHT menunjukkan bahwa instrumen soal penalaran matematis tersebut reliabel.

Uji normalitas dilakukan dari hasil tes akhir (post-test). Dalam penelitian ini, digunakan rumus Kolmogorov Smirnov dan Shapiro Wilk, dengan bantuan Spss 23. Berdasarkan hasil uji normalitas sampel berdistribusi normal. Uji persyaratan yang kedua yakni uji homogenitas. Dalam penelitian ini, digunakan uji lavene statistik dengan bantuan Spss 23. Berdasarkan hasil uji homogenitas dapat disimpulkan bahwa data pre-test dan post-test adalah homogen. Setelah uji normalitas dan uji homogenitas, selanjutnya dilakukan uji t.

Nilai kelas eksperimen Jigsaw hampir sama dengan kelas eksperimen NHT dimungkinkan karena pemberian perlakuan sama-sama menarik bagi siswa dan kesamaan penerapan metode kooperatif. Trianto (2009) memaparkan bahwa terdapat empat pendekatan yang seharusnya merupakan bagian kumpulan strategi guru dalam menerapkan model pembelajaran kooperatif, yaitu Student Team Achievment Division (STAD), Jigsaw, Group Investigation (GI), Teams Games Tournaments (TGT), dan pendekatan struktural yang meliputi Think Pair Share (TPS) dan Numbered Head Together (NHT). Berdasarkan hal ini model pembelajaran Jigsaw dan Numbered Head Together (NHT) memiliki beberapa langkah atau tahapan yang sama, yaitu membentuk kelompok yang terdiri dari 5-6 siswa, bertukar pikiran dalam kelompok untuk memecahkan masalah bersama, dan mempresentasikan jawaban. Dari langkah-langkah pembelajaran yang sama tersebut membuat indikator penalaran matematis dapat muncul pada model pembelajaran Jigsaw dan Numbered Head Together (NHT).

Penerapan model pembelajaran Jigsaw dan model pembelajaran Numbered Head Together (NHT) mampu meningkatkan kemampuan penalaran matematis siswa kelas V SDN Kedungringin III namun tidak terdapat perbedaan kemampuan kemampuan penalaran matematis siswa kelas V SDN Kedungringin III. Hal ini didapat dari uji hipotesis yang dilakukan pada data kemampuan akhir (post-test). Uji hipotesis digunakan uji independent sample t-test dengan bantuan SPSS 23. Ringkasan hasil perhitungan pengujian hipotesis terhadap data posttest kedua sampel disajikan pada tabel berikut.

Tabel 1. Hasil Perhitungan Pengujian Hipotesis

\begin{tabular}{lllllll}
\hline Kelas & Mean & Sig & df & thitung & tabel & Sig. (2 tailed) \\
\hline Eksperimen Jigsaw & 78,4 & 0,164 & 57 & 0,878 & 2,002 & 0,384 \\
Eksperimen NHT & 75,95 & & & & & \\
\hline
\end{tabular}

Berdasarkan tabel 1 tersebut, taraf signifikansi yang digunakan yaitu 5\% $(0,05)$ dan harga $t_{\text {hitung }}<t_{\text {tabel }}$ yaitu $0,878<2,002$. Nilai Sig. (2-tailed) $>0,05$ yaitu 0,384 $>0,05$ maka $\mathrm{H}_{0}$ diterima dan $\mathrm{H}_{\mathrm{a}}$ ditolak. Jadi, tidak ada perbedaan kemampuan penalaran matematis siswa 
kelas $\mathrm{V}$ dengan menggunakan model pembelajaran Jigsaw dan model pembelajaran Numbered Head Together (NHT).

\section{Simpulan}

Berdasarkan paparan data, maka dapat ditarik kesimpulan bahwa: (i) hasil kemampuan penalaran matematis siswa kelas $\mathrm{V}$ dengan menggunakan model pembelajaran Jigsaw memiliki rata-rata kemampuan akhir sebesar 78,4; (ii) hasil kemampuan penalaran matematis siswa kelas V dengan menggunakan model pembelajaran NHT memiliki rata-rata kemampuan akhir sebesar 75,95; (iii) tidak ada perbedaan kemampuan penalaran matematis siswa kelas $\mathrm{V}$ dengan menggunakan model pembelajaran Jigsaw dan model pembelajaran Numbered Head Together (NHT). Tidak adanya perbedaan tersebut dibuktikan dengan hasil perhitungan independent sample $t$-test yakni $t_{\text {hitung }}$ sebesar 0,878 dengan harga $t_{\text {tabel }}$ lebih besar yakni 2,002 pada df 57. taraf signifikansi yang digunakan yaitu $5 \%(0,05)$ dan harga $t_{\text {hitung }}<t_{\text {tabel }}$ yaitu 0,878 $<2,002$. Nilai Sig. (2-tailed) $>0,05$ yaitu 0,384 > 0,05 maka $\mathrm{H}_{0}$ diterima dan $\mathrm{H}_{\mathrm{a}}$ ditolak.

\section{Daftar Rujukan}

Aeni, N. N. (2008). Peningkatan Kemampuan Penalaran Siswa Dalam Pembelajaran Matematika Melalui Pendekatan Belajar Kooperatif Tipe Jigsaw Pada Pokok Bahasan Persamaan Garis Lurus, (Online), (http://eprints.ums.ac.id/791/), diakses 1 Juli 2020.

Andira, T., Santoso, B., \& Yusup, M. (2018). Penerapan model pembelajaran reciprocal teaching ditinjau dari kemampuan penalaran matematis peserta didik pada materi bangun datar segiempat Applying of reciprocal teaching learning model viewed from students' mathematical reasoning on quadrilateral mat. Pythagoras, 13(1), 88-98.

Annisah, Zulkardi, \& Darmawioyo. (2011). Pengembangan soal-soal model PISA pada konten quantity untuk mengukur kemampuan penalaran matematis peserta didik di SMP 1 Lubuklinggau. Jurnal Pendidikan Matematika, 5(1): 1-15.

Herman, T. (2007). Pembelajaran Berbasis Masalah Untuk Meningkatkan Kemampuan Penalaran Matematis Siswa SMP. Jurnal Cakrawala Pendidikan, 16(1), 41-62,

Jelatu, S., Amul, M. I., Jeramat, E., \& Jundu, R. (2019). Model Pembelajaran Kooperatif Tipe Numbered Head Together (NHT) Terhadap Kemampuan Penalaran Matematika Siswa. Jurnal Pendidikan Matematika Indonesia, 4(1), 12-17.

Manshur, M. (2013). Perbedaan Hasil Belajar Materi Baterai Antara Model Pembelajaran Kooperatif (Jigsaw dan Numbered Head Together) dengan Model Pembelajaran Ekspositori. Skripsi diterbitkan. Semarang: Universitas Negeri Semarang

Rahmiati \& Pianda, D. (2018). Strategi dan Implementasi Pembelajaran Matematika di Depan Kelas. Sukabumi: CV Jejak,

Salam, M. dan Junta, A.. (2012). Perbedaan Hasil Belajar Matematika Ditinjau dari Model Pembelajaran Kooperatif Tipe TSTS dan Tipe STAD. Jurnal Pendidikan Matematika, 3(2), 187-200,

Sumartini, T. S. (2015). Peningkatan Kemampuan Penalaran Matematis Siswa Melalui Pembelajaran Berbasis Masalah. Jurnal Pendidikan Matematika, 5(1), 1-10,

Trianto. (2009). Model-model Pembelajaran Inovatif Berorientasi Kontruktivistik. Jakarta: Prestasi Pustaka Publisher. 